\title{
Creation of Primary Cell Lines from Lineage-Labeled Mouse Models of Cancer
}

\author{
Andrew D. Rhim ${ }^{1}$ \\ Division of Gastroenterology, Department of Internal Medicine, University of Michigan Medical School, Ann \\ Arbor, Michigan 48109
}

Frequently, it is necessary to isolate pure populations of cancer cells for downstream assays, such as transcriptional analysis, signaling studies, and the creation of noncontaminated primary cell lines. Genetic lineage labeling with fluorescent reporter alleles allows for the identification of epithelialderived cells within tumors. This protocol describes a method to isolate lineage-labeled pancreatic epithelial cells for ex vivo analysis, but it can be adapted for any type of lineage-labeled tumor.

\section{MATERIALS}

It is essential that you consult the appropriate Material Safety Data Sheets and your institution's Environmental Health and Safety Office for proper handling of equipment and hazardous materials used in this protocol.

RECIPES: Please see the end of this protocol for recipes indicated by $<R>$. Additional recipes can be found online at http://cshprotocols.cshlp.org/site/recipes.

Reagents

Collagenase with protease inhibitors (Sigma-Aldrich C6079)

Prepare at a concentration of $1 \mathrm{mg} / \mathrm{mL}$ in DMEM/F12 (Life Technologies 11330-032).

DAPI (4',6-diamido-2-phenylindole) (3 nм)

Dulbecco's modified Eagle's medium (DMEM)/F12, prechilled to $4^{\circ} \mathrm{C}$

DMEM/F12 containing 10\% fetal calf serum (FCS), prechilled to $4^{\circ} \mathrm{C}$

Mice with cells/tissues that have been labeled using any fluorescent fluorophore

This protocol describes how to isolate yellow fluorescent protein (YFP)-labeled pancreatic epithelial cells from mice. The mice can be genetically engineered to develop tumors (e.g., Pdx-Cre; LSL-Kras ${ }^{\mathrm{G} 12 \mathrm{D} / \mathrm{H}^{+}}$; p53 $3^{\mathrm{fl} /+^{+}}$; Rosa26 $\left.6^{(S L-Y F P}\right)$.

Pancreatic ductal epithelial cell (PDEC) medium $<\mathrm{R}>$

Trypsin-EDTA $<$ R $>$

Equipment

Cell strainer (40 $\mu \mathrm{m}$; BD Biosciences 352340)

Cell strainer tube (contains $40-\mu \mathrm{m}$ strainer in the cap; BD Biosciences 352235)

Conical centrifuge tubes $(50 \mathrm{~mL})$

\footnotetext{
${ }^{1}$ Correspondence: arhim@mail.med.umich.edu

(c) 2015 Cold Spring Harbor Laboratory Press

Cite this protocol as Cold Spring Harb Protoc; doi:10.1101/pdb.prot078287
} 
A.D. Rhim

Dissecting instruments (sterile)

Fluorescence-activated cell sorting (FACS) instrument

Hemocytometer or other cell counter

Needles (16-18 gauge)

Syringes $(5 \mathrm{~mL})$

Tissue-culture dishes

Tissue-culture incubator $\left(37^{\circ} \mathrm{C}\right.$ and $\left.5 \% \mathrm{CO}_{2}\right)$

Tissue-culture plates (six well)

1. Kill a mouse. Dissect the pancreas quickly.

2. Place the pancreas in a $50-\mathrm{mL}$ beaker with $\sim 5-10 \mathrm{~mL}$ of cold DMEM/F12. Swirl and decant.

3. Wash the pancreas twice more, each time with 5-10 mL of cold DMEM/F12. After the third wash, pour off as much of the media as possible.

4. Mince the pancreas with sterilized scissors into small pieces of roughly $\sim 1 \mathrm{~mm}$ in length. Approximately 100 chops will do. Larger tumors will require approximately 200 chops.

5. Add $10 \mathrm{~mL}$ of $1 \mathrm{mg} / \mathrm{mL}$ collagenase/protease inhibitors in DMEM/F12 to the minced pancreas. Transfer to a $50-\mathrm{mL}$ tube and vortex.

6. Incubate for $20 \mathrm{~min}$ at $37^{\circ} \mathrm{C}$. Vortex every $5 \mathrm{~min}$.

7. After $20 \mathrm{~min}$, vortex and pour the mixture into a $40-\mu \mathrm{m}$ cell strainer that has been seated in a 50 $\mathrm{mL}$ centrifuge tube.

8. Dilute the filtrate with cold DMEM/F12 to $50 \mathrm{~mL}$. Cap and centrifuge at $900 \mathrm{~g}$ for $5 \mathrm{~min}$ at $\sim 10^{\circ} \mathrm{C}$.

9. Decant and resuspend the cell pellet in $25 \mathrm{~mL}$ of cold DMEM/F12 containing $10 \%$ FCS. Place on ice.

10. Remove the cell strainer and place upside down in a culture dish. Use a scalpel to cut the filter from the plastic. Using sterile forceps remove the filter and place it in a culture dish with the tissue facing up. Immerse the tissue in $0.05 \%$ trypsin-EDTA prewarmed to $37^{\circ} \mathrm{C}$.

11. Transfer the contents of the dish to a $50-\mathrm{mL}$ tube and vortex. Incubate for $5 \mathrm{~min}$ in a $37^{\circ} \mathrm{C}$ water bath, vortexing every 2 min.

12. Place a $40-\mu \mathrm{m}$ strainer over the 50 - $\mathrm{mL}$ centrifuge tube containing collagenase-released cells (from Step 9). Pour the trypsin-treated tissue into the strainer. Discard the strainer and fill the tube with DMEM/F12 to $50 \mathrm{~mL}$.

See Troubleshooting.

13. Centrifuge at $900 \mathrm{~g}$ for $5 \mathrm{~min}$ at $\sim 10^{\circ} \mathrm{C}$. Decant, and resuspend the cells in $50 \mathrm{~mL}$ of DMEM/F12.

14. Repeat Step 13 two more times, but after the final wash, resuspend the cells in $1 \mathrm{~mL}$ of cold DMEM/F12 containing 10\% FCS.

15. Remove an aliquot and use to determine the cell concentration.

16. Add $1 \mu \mathrm{L}$ of $3 \mathrm{~nm}$ DAPI to the cells, mix by pipetting, and incubate on ice for $10 \mathrm{~min}$.

17. Centrifuge at $900 \mathrm{~g}$ for $5 \mathrm{~min}$ at $10^{\circ} \mathrm{C}$.

18. Decant, and add DMEM/F12 containing 10\% FCS to the cell pellet to a final concentration of $1 \times$ $10^{6}-1 \times 10^{7}$ cells $/ \mathrm{mL}$.

19. Aspirate the cell suspension into a 5 -mL syringe with a 16- to 18-gauge needle. Remove the needle.

20. Affix the syringe to a cell strainer FACS tube and transfer the cell suspension over 20-30 sec. 
21. Sort $\mathrm{YFP}^{+}$cells into a 5-mL tube containing $2 \mathrm{~mL}$ of cold DMEM/F12 containing $10 \%$ FCS. Make sure that the sort tubes are chilled before beginning the cell sorting. See Troubleshooting.

22. Centrifuge the $\mathrm{YFP}^{+}$tube at $900 \mathrm{~g}$ for $5 \mathrm{~min}$ at $\sim 10^{\circ} \mathrm{C}$.

23. Decant and resuspend the cell pellet in $1.2 \mathrm{~mL}$ of PDEC medium. Transfer the cells to a six-well plate $(200 \mu \mathrm{L} /$ well $)$. Place the plate in a tissue-culture incubator at $37^{\circ} \mathrm{C}, 5 \% \mathrm{CO}_{2}$. Allow the cells to settle for $30 \mathrm{~min}$.

24. Flood each well with $3 \mathrm{~mL}$ of $37^{\circ} \mathrm{C}$ PDEC medium and return the plate to the incubator. Incubate the cells for $24 \mathrm{~h}$.

25. Remove the medium (and dead cells). Refeed with $5 \mathrm{~mL}$ of $37^{\circ} \mathrm{C}$ PDEC medium per well.

26. Refeed with $37^{\circ} \mathrm{C}$ PDEC medium every $2-3 \mathrm{~d}$ and passage with $0.05 \%$ trypsin-EDTA when the cells are $40 \%-50 \%$ confluent. Thereafter, passage when the cells are $80 \%$ confluent.

See Troubleshooting.

\section{TROUBLESHOOTING}

Problem (Step 12): A large amount of tumor tissue remains on the cell strainer after trypsin treatment. Solution: Tumors rich in stroma and fibrosis are difficult to digest. However, one must weigh the yield of additional digestion with negative effects on cell viability. This protocol has been optimized to yield viable cells but with incomplete tumor digestion.

Problem (Step 21): The number of live $\mathrm{YFP}^{+}$cells is low.

Solution: The yield for viable $\mathrm{YFP}^{+}$primary tumor cells varies with tissue type. For pancreatic tumors, yield is typically low, possibly because of autodigestion by pancreatic digestive enzymes. Keep cells on ice and in the dark as much as possible. Perform this procedure quickly, including transferring the sorted cells to culture. We take $\sim 1.25 \mathrm{~h}$ to prepare cells for sorting.

Problem (Step 26): Cells are not growing.

Solution: If cells are not $40 \%-50 \%$ confluent after $1 \mathrm{wk}$, then lift the cells with trypsin-EDTA and transfer them to a new six-well plate.

\section{DISCUSSION}

This protocol, which is adapted from Rhim et al. (2012), has been used extensively by our laboratory to establish pure epithelial primary tumor lines from lineage-labeled mouse models. This approach ensures that fibroblast contamination, a frequent problem in the generation of primary cancer cell lines, does not occur. This protocol can be used for any type of lineage-labeled tumor, although it has been optimized for pancreatic cancer.

The major drawback to this protocol is potential bias introduced in creating the cell lines. Multiple steps in this protocol are likely to lead to some degree of artificial selection of cells for culture (e.g., extended periods of time in which cells are in suspension and the high-pressure forces applied to cells during flow sorting). Further, YFP labeling can be heterogeneous within tumor cells that can provide a challenge in creating gates on FACS.

Because this protocol generates a single-cell suspension of primary tumor cells, this approach lends itself to several modifications. It is possible to stain cells for various surface epitopes for subgroup analysis. We have established cultures of subsets of tumor cells that contain various putative cancer stem cell markers using this approach with success. In addition, a portion of sorted cells can be dedicated for RNA and DNA extraction. Finally, depending on the flow cytometer available, single cells can be sorted directly into ultralow attachment plates for assessment of clonal growth and selfrenewal (Rovira et al. 2010). 
A.D. Rhim

Genetic lineage labeling allows for the creation of "pure" primary cancer cell lines, and therefore a more accurate assessment of cancer cells in vitro. As downstream analyses of primary murine cell lines continue to evolve, including genomic and clonal analyses, it will be vital to ensure the purity of the material being analyzed.

\section{RECIPES}

Pancreatic Ductal Epithelial Cell Medium

\begin{tabular}{|c|c|}
\hline Reagent & Amount \\
\hline DMEM/F12 (Life Technologies 11330-032) & $500 \mathrm{~mL}$ \\
\hline D-Glucose (Sigma-Aldrich G5400) & $2.5 \mathrm{~g}$ \\
\hline Nicotinamide (Sigma-Aldrich N3376) & $0.61 \mathrm{~g}$ \\
\hline Soybean trypsin inhibitor (type 1; Sigma-Aldrich T6522) & $50 \mathrm{mg}$ \\
\hline ITS+ Premix (BD Biosciences 354352) & $2.5 \mathrm{~mL}$ \\
\hline $\begin{array}{l}\text { Bovine pituitary extract (BD Biosciences } 354123 ; 3 \mathrm{mg} / \mathrm{mL} \\
\text { in DMEM/F12) }\end{array}$ & $4.2 \mathrm{~mL}$ \\
\hline $3,3^{\prime}, 5$-Triiodo-L-thyronine $(\mathrm{T} 3 ; 50 \mathrm{~nm})^{\mathrm{a}}$ & $50 \mu \mathrm{L}$ \\
\hline Dexamethasone (Sigma-Aldrich D1756; 100 mм in DMSO) & $5 \mu \mathrm{L}$ \\
\hline Nu-serum IV (BD Biosciences 355104) & $25 \mathrm{~mL}$ \\
\hline Cholera toxin (Sigma-Aldrich C8052; $1 \mathrm{mg} / \mathrm{mL}$ in $\mathrm{H}_{2} \mathrm{O}$ ) & $50 \mu \mathrm{L}$ \\
\hline Penicillin-streptomycin (100×; Life Technologies 15140-122) & $5 \mathrm{~mL}$ \\
\hline Fungizone & $2.5 \mathrm{~mL}$ \\
\hline
\end{tabular}

Trypsin-EDTA

$0.05 \%$ trypsin

$0.5 \mathrm{~mm}$ EDTA (pH 8.0)

\section{ACKNOWLEDGMENTS}

This work was supported by the National Institutes of Health (DK088945), the Penn Center for Molecular Studies in Digestive and Liver Diseases (P30-DK050306), the National Pancreas Foundation, and the American Gastroenterological Association (Fellow to Faculty award).

\section{REFERENCES}

Rhim AD, Mirek ET, Aiello NM, Maitra A, Bailey JM, McAllister F, Reichert M, Beatty GL, Rustgi AK, Vonderheide RH, et al. 2012. EMT and dissemination precede pancreatic tumor formation. Cell 148: 349-361.
Rovira M, Scott SG, Liss AS, Jensen J, Thayer SP, Leach SD. 2010. Isolation and characterization of centroacinar/terminal ductal progenitor cells in adult mouse pancreas. Proc Natl Acad Sci 107: 75-80. 


\section{Creation of Primary Cell Lines from Lineage-Labeled Mouse Models of Cancer}

Andrew D. Rhim

Cold Spring Harb Protoc; doi: 10.1101/pdb.prot078287

\begin{tabular}{|c|c|}
\hline $\begin{array}{r}\text { Email Alerting } \\
\text { Service }\end{array}$ & Receive free email alerts when new articles cite this article - click here. \\
\hline $\begin{array}{r}\text { Subject } \\
\text { Categories }\end{array}$ & $\begin{array}{l}\text { Browse articles on similar topics from Cold Spring Harbor Protocols. } \\
\text { Cell Culture ( } 301 \text { articles) } \\
\text { Flow Cytometry (42 articles) } \\
\text { Mouse (437 articles) } \\
\text { Transgenic Mice (139 articles) }\end{array}$ \\
\hline
\end{tabular}

